\title{
CORPORATE POLITICAL CONNECTIONS IN GLOBAL STRATEGY
}

\author{
Lin Cui (lin.cui@anu.edu.au), Australian National University ${ }^{1}$ \\ Helen Wei Hu (hehu@unimelb.edu.au), University of Melbourne \\ Sali Li (sali.li@moore.sc.edu), University of South Carolina \\ Klaus E. Meyer (meyer@ivey.uwo.ca), Ivey Business School, Western University
}

Version: June 8, 2018

\section{Research Summary}

The role of corporate political connections (CPC) in global strategy has been examined in a variety of institutional contexts and analyzed from different theoretical perspectives. This literature along with the papers in this special issue, demonstrate the importance of contextualization in understanding the motivations, processes, and outcomes of firms developing and utilizing CPC in global strategy. We argue that context specific aspects of CPC, such as the political system in which the firm is operating, need to be incorporated more systematically to advance theory development globally. Future studies on CPC can advance this agenda through cross-country comparative research, deeper engagement with political science literature, linking CPC with other non-market strategies, and configurational analysis of the multidimensional context of CPC.

\section{Managerial Summary}

Multinational companies not only compete in a market environment, they engage with political actors in both their home and host societies. This special issue brings together research that explores how companies use their corporate political connections (CPC) to achieve firm objectives. Each study takes a different approach to studying the phenomenon, informed by the national context of their empirical data. Together, these studies highlight the importance of CPC around the world. However, the variation in research approaches also highlights that the 'how and why' of companies' development and utilization of CPC vary across cultures and political systems. In consequence, the development of managerial recommendations always needs to carefully consider the pertinent political context of the available empirical evidence available.

Keywords: corporate political connections (CPC), non-market strategy, business-government relations, political capabilities, political systems, contextualization.

\footnotetext{
1 Authors listed in alphabetical order.
} 


\section{Introduction}

Corporate political connections (CPC) are the 'boundary spanning personal and institutional linkages between firms and the constituent parts of public authorities' (Sun, Mellahi \& Wright, 2012:68). Also known as political ties, CPC are a global phenomenon that has attracted recent research in management (Hillman \& Keim, 1995; Sun, et al., 2012), economics (Acemoglu, et al., 2016; Faccio, 2006; Goldman et al. 2009), political economy (Hansen \& Mitchell, 2000; Jensen, 2008) and other disciplines. Recent strategic management studies analyze CPC primarily as a resource (Frynas, Mellahi \& Pigman, 2006; Holburn \& Zelner, 2005; Lester, Hillman, Zardkoohi \& Cannella, 2008) that is deployed within corporate non-market strategies (Doh, Lawton \& Rajwani, 2012; Oliver \& Holzinger, 2008).

CPC capture a broad range of interactions between actors in business and government for mutual benefits. Businesses may, for example, use CPC to network with powerful political actors, to obtain preferential access to information on forthcoming regulatory changes, or to influence the interpretation of such rules in their favor (Sun, Mellahi, \& Wright, 2012). As such, CPC can be deployed for influence strategies, be they legal (e.g. lobbying) or illegal (e.g. corruption). CPC have been shown to enhance, in many circumstances, organizational legitimacy (Li, Meyer, Zhang \& Ding, 2018; Sheng, Zhou \& Li, 2011), competitive advantages (e.g. Brockman, Rui, \& Zou, 2013; Frynas, Mellahi, Pigman GA, 2006; Siegel 2007; Yan and Chang, 2018), and survival (Zheng, Singh, \& Mitchell, 2015).

However, the nature and role of CPC are subject to important contingencies that are not yet well understood in the literature (Sun et al., 2012). In other words, the value of CPC and the costs associated with creating CPC are contingent on, for example, political systems, regulatory institutions (Holburn \& van den Bergh, 2008; Mbalyohere et al., 2017; Zheng, Singh, \& Chung, 2017) and industry characteristics (Ramamurti, 2000; Wocke \& Moodley, 2015). This is a particular concern for global strategy research as multinational enterprises (MNEs) potentially interact with political agents in multiple locations, and it is not clear to what extend learnings from one context are transferable to other contexts. Therefore, theories need to be contextualized both for empirical testing and to develop managerial insights on how MNEs can acquire, develop, and exploit CPC. 
The quest for a general theory in a field subject to a plethora of contextual influences calls for an integration of emic and etic approaches to theory building (Leung, 2009; Morris, Leung, Ames \& Lickel, 1999;). Specifically, management scholars typically take an etic approach to theorizing about CPC - an approach that takes the perspective of an outsider and focuses on constructs that apply across contexts. However, many studies investigate CPC in single countries and adopt (often implicitly) an emic approach - an approach informed by deep insider knowledge of the local context, but generating theoretical insights that may not transfer to other contexts. The emic perspective is particularly important in the development of empirical measurements: through their understanding of the local context, scholars can develop measurements that capture locally relevant aspects of their focal constructs (Farh, Cannella, \& Lee, 2006). For example, the individuals acting as business-government interfaces and the mechanisms they use to influence the other side vary across countries. Therefore, local knowledge is important to develop valid proxies and scales.

Various scholars have highlighted the merits of bringing together emic and epic approaches to theorizing in management research, notably on the construct of culture (Leung, 2009; Morris et al., 1999; Whetten, 2009). Based on our review, we propose that CPC represent a phenomenon in management scholarship where not only iteration between of emic and etic studies can advance theory development, as recommended by Morris et al. (1999) and others, but where being more explicit about the interplay between emic and etic approaches would greatly enhance research progress.

This introduction to the special issue on CPC and global strategies explores how scholars of international business and global strategy have applied and contributed to CPC research. Following a brief reflection on the different locations where MNEs may develop and deploy CPC, we review CPC research in international business considering the research phenomena, contexts and theoretical lenses. This review highlights the importance of context for many of the research questions posed by CPC researchers, and in consequence the challenges faced by MNEs operating in multiple national contexts. We then set the special issue articles in the context of this research. On this basis, we offer suggestions on how to better address generalizability and contextualization to advance $\mathrm{CPC}$ research, and conclude with 
suggestions for future research, calling especially for more explicit consideration of the generalizability and context-specificity of insights on CPC in international business.

\section{CPC and Global Strategy}

MNEs are embedded simultaneously in multiple national economies, including in particular the home country and each host country in which the MNE is operating (Meyer, Mudambi, \& Narula, 2011). As they develop their global strategy, MNEs may build and deploy CPC in both home and host countries. However, the national political actors may also interact directly with each other, while multilateral institutions increasingly interact directly with MNEs. Thus, MNEs may develop and deploy their CPC in four forums.

First, international business scholars have traditionally focused on host countries. MNEs cultivate CPC in their host countries to manage their risk exposure, notably in situations of obsolescent bargain (Eden, Lenway, \& Schuler, 2005; Kobrin, 1987; Müllner \& Puck, 2018). Recent studies show that MNEs' political strategies help to realize first-mover advantages (Frynas et al., 2006) and to reduce their exposure to host country risks, especially in institutionally fragile, emerging economies (Ma \& Delios, 2010; Puck et al., 2013). However, as highlighted by Heidenreich, Mohr, and Puck (2015), political strategies can also lead to overconfidence of foreign investors and compromise their survival. Especially in politically instable or nontransparent environments, managing CPC locally is likely a major challenge for subsidiary managers.

Second, MNEs may develop CPC in their home country with the aim of mobilizing resources to enhance their global operations. The extent to which such home country CPC help or hinder MNEs' international strategies, however varies with the political institutions of the home country (Estrin et al., 2016; Fernández-Méndez et al., 2018; Huang et al. 2017). For example, many political actors are only concerned with the economic development of the home country, and would thus discourage overseas investment, notably if it involves production activity abroad that could be done at home (offshoring would be a prime example of this). On the other hand, in some industries and home countries, foreign investment is actively encouraged by political actors suggesting that CPC would lead to more international investment. In particular, with the policy priorities of the Chinese authorities, investment by 
Chinese MNEs with strong CPC is associated with increased technology or natural resource seeking abroad (Morck et al., 2008). On the other hand, in India, Choudhury and Khanna (2014) argue that equity ties with the home government can motivate Indian firms to venture into international markets as a diversification tactic to reduce their dependence on the home government.

Third, the interaction between political actors in home and host countries influences how and where firms use CPC. As Stopford and Strange (1991) discussed two decades ago, MNEs, home governments and host governments interact in a tri-lateral relationship. MNEs may thus use home country $\mathrm{CPC}$ to engage the home government to take initiatives toward the host country ranging from the ambassador having a chat with local counterparts to governments negotiating a wide-ranging free trade agreement. Recent studies explored such bilateral government relationships for Chinese MNEs (Child and Marinova. 2014). For example, Li et al. (2013) examine how in intergovernmental agreements create infrastructure projects in the host country (in Africa, in their study) for which the home country (China) not only arranges the funding but selects suitable contractors. More generally, Li et al. (2018) argue that CPC at home help firms to access diplomatic networks, which generates a number of potential advantages for the well-connected investors, and thus makes it more likely a host country with strong diplomatic ties is chosen for an investment project.

Finally, in addition to bilateral government interactions, MNEs increasingly engage with multilateral policy forums or transnational organizations such as the European Union, the UN Global Compact, or the Climate Change Conferences (Dahan, Doh \& Guay, 2006; Ramamurti, 2001). At this supra-national level, business lobbying often occurs through industry associations rather than by firms directly, though some large MNEs may take their own lobbying initiatives (Kautto, 2009). Thus, as MNEs develop their strategies globally, they may develop and deploy CPC in multiple forums. We next review the insights the international business literature has to offer on CPC.

\section{CPC in International Business: A Literature Review}

Governments and other political actors shape the environment for business. Thus, businesses develop and deploy CPC with the aim of influencing decision makers in the political sphere 
of a country. From a business perspective, CPC are formal and informal ties between business and political actors, as well as purposeful interactions by business actors with their contacts in government agencies. However, political systems and the institutions governing business-to-government interactions vary widely among countries. These cross-country differences in political systems and institutions increase the complexity of political activities of firms operating in multiple national contexts.

CPC have been examined in several scholarly disciplines, such as political economy (Jensen, 2008), political science (Hansen \& Mitchell, 2000), economics (Fisman, 2001), and business (Hillman 2005). Within this broad literature, we are specifically interested in the challenges of managing CPC as part of global strategy, and hence by firms that are simultaneously interacting with political and economic stakeholders in multiple countries. Ultimately, we aim to facilitate theory development in global strategy, and how consideration of CPC may enhance this endeavor. Therefore, we have conducted a systematic review of CPC-related research in the field of international business.

Specifically, we have collected all prior studies on CPC through a systematic search using keywords related to political connections (see note 1 of Table 1) over the past three decades in six leading international business journals from 1990 to 2018: Journal of International Business Studies, Journal of World Business, Global Strategy Journal, International Business Review, Management International Review and Journal of International Management. ${ }^{2}$ Statistics of the thus created database of papers show that CPC have attracted increasing attention across all major international business research outlets (see Table 1). The surge of interest is related to the quest for appropriate theories that can explain international business phenomena in emerging economies where CPC are argued to be particularly important (Meyer \& Grosse, 2018; Meyer \& Peng, 2016; Sun, 2018).

[place Table 1 about here]

\footnotetext{
${ }^{2}$ We also searched general management journals, but very few papers in these outlets explicitly address both CPC and international themes; these are cited where appropriate in the text. The only paper before 1990 that addresses CPC is Boddewyn (1988).
} 
The literature can be organized into four main phenomenological areas, which have been examined through a variety of theoretical lenses. The linkage between phenomena and theoretical perspectives is bi-directional as empirical studies both apply and advance existing theories. Contextualization occurs in both directions: research designs take into account local contexts, while context-specific research insights inform the boundary conditions of theories and contextual moderators in theoretical models.

\section{CPC research phenomena}

The first phenomenological area in this literature focuses on developing the CPC concept. International business scholars have traditionally focused on MNE-government relationships focusing on host countries, and analyzing bargaining relationships between MNEs and host governments (Grosse, 2004; Murtha \& Lenway, 1994; Ramamurti, 2001; Stopford \& Strange 1991). Recent international business research further explores CPC as a concept nested in the broader research on non-market strategies (Boddewyn, 2016; Doh \& Lucea, 2013). Scholars also offer new typologies aiming towards a more fine-grained understanding of CPC. For example, Jia (2018) distinguishes two types of political lobbying activities of firms - inhouse lobbying and outsourced lobbying - and suggests that firms' decision between these options is driven by economic efficiency maximization. Luo (2004) develops a typological framework for understanding MNE-host government relationships, which recognizes that this relationship contains competitive and cooperative elements simultaneously. Rizopoulos and Sergakis (2010), conversely, propose a stylized taxonomy of MNEs' political leverage in the home country, taking into consideration the type of home-country policy network and MNEs' position inside that network. Overall, these conceptual studies highlight that CPC can take a variety of forms as firms aim to pursue the most viable channel and strategic positioning for firms to engage with political actors in different institutional and political contexts.

The second set of phenomena concerns the antecedents of CPC. These antecedents are both external and internal to the focal firm, and multilevel in nature. MNEs build host country CPC and engage in political strategies in response to both political pressures and economic incentives shaped by the host environment and the MNEs' resource dependence in the host economy. For instance, Hillman and Wan (2005) find that both parent company and 
host country pressures determine the political strategies used by foreign subsidiaries of MNEs to attain internal and external legitimacy. Similarly, Buckley, Clegg, and Tan (2006) suggest that personal level cultural awareness of MNE managers influences their effort to build CPC with local governments in a host country. In the case of sovereign wealth funds, Calluzzo, Dong, and Godsell (2017) find that shocks in the external environment influence their investment in politically connected local firms. More generally, firms' needs for various local resources motivate them to engage in different types of political strategies to manage their external dependence (Shirodkar \& Mohr, 2015). Jointly, these studies suggest that how and why businesses utilize CPC are contingent on the environment and resources they are operating with.

Third, the majority of the reviewed studies examine the consequences of CPC. Scholars have investigated the influence of both home country and host country CPC on strategic choices and performance outcomes of MNEs. A major form of home country CPC is state ownership in MNEs, which can influence their propensity to enter foreign markets (Choudhury \& Khanna, 2014; Li, Cui, \& Lu, 2014, Xia et al., 2014), their location choice (Duanmu, 2012; Li et al., 2018), timing of foreign market entry (Hennart, Sheng, \& Carrera, 2017), mode of foreign market entry (Cui \& Jiang, 2012), entry success (Li, Xia, \& Lin, 2017; Meyer \& Altenborg, 2008), and post-entry performance (Tse, Yu, \& Zhu, 2017; Zou \& Adams, 2008). In the host country, CPC with host governments can influence MNEs' mode of entry (Chen et al., 2017), realization of first-mover advantages (Frynas et al., 2006), international joint venture control method (Chen, Paik, \& Park, 2010), and ownership decisions (Pinto et al., 2016).

The large number of studies in this area also exposes some inconsistencies in the theoretical arguments and empirical findings. Such inconsistencies can be due to the differences in research context, which highlights the importance of contextualization of CPC studies. Essentially, CPC help firms to deal with external constraints, and therefore, the effectiveness of CPC activities is necessarily contingent on the power dynamics and dependencies between firms and the political entities who impose the constraints. Such power dynamics and dependencies vary with the political setting the firms operate in (Rizopoulos \& Sergakis, 2010), the firms' own capabilities (Jia, 2018), and the alignment or misalignment of 
incentives between the firms and political actors (Luo, 2004). These contingencies vary across and within countries, and therefore single-context studies are likely to produce context-specific findings that may not be applicable outside the research setting. Even among China-focused studies results are inconsistent. For example, some scholars, from a political perspective, argue that home state ownership represents a hindrance for foreign market entry (e.g. Cui \& Jiang, 2012; Huang et al., 2017), while others, from a resource perspective, view this as a source of home institutional support for foreign expansion (e.g. Morck, Yeung \& Zhao, 2008; Yamakawa, Peng, \& Deeds, 2008). Both arguments have theoretical merits. However, the relative importance of the liability of stateness versus strategic support for internationalization varies across industries, size of the firm, institutional development over time, and other contextual features.

Fourth, CPC influence firm behavior in global strategy not only as an independent factor, but contingent on the internal and external context in which the firm operates. In terms of internal factors, for instance, Li, Zhou, and Shao (2009) show that the interaction between $\mathrm{CPC}$ and competitive strategy influences profitability of foreign firms in China. Similarly, the effect of state ownership on firms' internationalization is contingent on firms' entrepreneurial characteristics (Zhang et al., 2016). In terms of external contingencies (which speak to the contextual variations we address later), the impact of CPC on internationalization is moderated, for example, by home country characteristics such as government effectiveness (Estrin et al., 2016; Wu \& Zhao, 2015) and by host country characteristics such as the legal enforcement and technological volatility (Sheng, et al. 2011).

Overall, while researchers have examined the contingent value of CPC for international business actors, individual studies selectively investigate certain contingencies rather than develop an integrative view of CPC in a complex nexus of causal relationships. Most of the studies have not truly employed a configurational approach, either theoretically or analytically. However, the combined insights from prior studies suggest that CPC interact with a wide range of internal and external factors. A configurational approach may thus be useful to consolidate these combined insights. This is demonstrated by Cui et al. (2017), who explore the 'causal recipes' of emerging MNEs' location choice based on configurations of 
these firms' host country political ties in conjunction with firm awareness, motivation, and capability factors.

\section{Theoretical lenses on CPC}

CPC are a cross-disciplinary phenomenon of interest to economists, political scientists, business strategists, and (micro-)management researchers. Prior studies adopt a variety of theoretical lenses, including most frequently new institutional economics, neo-institutional perspectives, resource dependence theory, corporate governance, and resource and learning perspectives (Table 2).

\section{[place Table 2 about here]}

New institutional economics focuses on the 'role of economic and industrial organization and the role of political governance in developing and maintaining these institutional structures' (Doh et al., 2012: 25). This theoretical lens emphasizes that political institutions shape the incentives of economic actors and set constraints on their strategic/behavioral choices. Deficiencies in formal institutional development create uncertainties regarding these incentives and constraints, which motive businesses to develop CPC to absorb the uncertainties (White, Boddewyn, \& Galang, 2015). The voids-bridging function of CPC in foreign markets, either through political strategies or by partnering with host country state-owned firms, can influence MNEs' entry strategies (Chen et al., 2017) as well as their performance (Brockman, Rui, \& Zou, 2013). However, strategies of deploying $\mathrm{CPC}$ in host countries can backfire and turn into liabilities when the political regime changes (Bucheli \& Salvaj, 2018; Siegel, 2007).

The neo-institutional perspective, or sociological institutionalism, focuses on social structures to explain 'homogeneity in organizational forms and practices' (DiMaggio \& Powell, 1983: 148; Kostova \& Marano, 2018). It covers regulatory, normative, and cognitive domains of social structures that exert coercive, normative, and mimetic isomorphic pressures on organizations. This theoretical lens suggests that foreign MNEs may face challenges in establishing their legitimacy in host countries, associated with their country of origin (Meyer et al. 2014; Puck, Roger \& Mohr, 2013; Stevens \& Newenham-Kahindi, 2017). In such a context, CPC in the host country may be an effective channel of obtaining political and social 
legitimacy in a foreign environment (Hillman \& Wan, 2005). For example, home country CPC may help firms to connect to intergovernmental diplomatic networks, and thereby to attain legitimacy in some foreign locations (Li et al., 2018). On the other hand, strong CPC in the home country can magnify legitimacy deficits in host countries that have ideological or political conflicts with the home country. Firms may thus design their entry mode such as to overcome such legitimacy deficits (Cui \& Jiang, 2012; Meyer et al., 2014).

Resource dependence theory is based on the premise that organizations rarely possess all of the resources required for their survival and development, and are therefore dependent on other organizations in the external environment for supplies of critical resources (Pfeffer \& Salancik, 1978). Political actors, such as governments, often have control over critical resources needed by businesses, resulting in a high dependence for the latter. One way of absorbing uncertainties from high external dependence is to build inter-organizational relationships. This explains why many MNEs build CPC or engage in political strategies in host countries to stabilize access to critical resources from the host government (Dielemann \& Boddewyn, 2012; Wu \& Zhao, 2015). Another way of dealing with high external dependence is to diversify the sources of critical resources. Through this perspective, home state dependence, as reflected in ownership connections with the home country government, can motivate firms to diversify into international markets as an escape tactic (Choudhury \& Khanna, 2014). However, too much dependence on the home country state may compromise strategic autonomy of the firm, and thus hinder their internationalization (Huang et al., 2017).

Agency theory has been adopted in many studies that examine the role of ownership particularly state ownership, a form of equity-based CPC, and managerial political ties, a form of relationship-based CPC, in the governance of firms. CPC introduce the government (or other political actors) as influential stakeholders who can impose their own objectives on the firm - possibly mediated by a hierarchy of control and hence multiple agency conflicts (Cuervo-Cazurra et al., 2014). The objectives of political stakeholders and the added complexities of the governance structures have been shown to influence firms' choice of growth strategies (Yang \& Meyer, 2018), their propensity to enter foreign markets (Estrin et al., 2016; Hu \& Cui, 2014), and their internationalization performance (Zou \& Adams, 2008). 
These studies suggest that strategic activities of firms, such as internationalization, need to be aligned with the interests of political actors who are connected to the firm through CPC.

Fifth, scholars have interpreted CPC as a capability or as a channel to access resources that may add value to the firms. From this perspective, CPC are the foundation of "political capabilities' (Holburn \& Zelner, 2010), 'political capital' (Siegel, 2007) or 'political resources' (Frynas, Mellahi \& Pigman, 2006) that enables firms to further their objectives in nonmarket spheres, and ultimately to enhance their competitive advantages (Sun et al., 2012a). Thus, CPC shape firms' resource accumulation and organizational learning processes, and thus their strategic choices. For example, Benito, Rygh, and Lunnan (2016) find that CPC help firms to reap greater benefits from internationalization. Moreover, knowledge on how to manage CPC may to some extent be transferable to other countries with similar political systems and business-to-government interactions (del Sol \& Kogan, 2007; Fernández-Méndez, García-Canal \& Guillén, 2018).

Similarly, CPC in the home country may enhance firms' absorptive capacity and thereby increase their gains from inward (e.g. spillovers from foreign direct investment) and outward internationalization (Liu, Wang, \& Wei, 2009; Wu et al., 2016). Conversely, CPC may inhibit the development of market-based competitive advantages at home, and thereby motivate foreign strategic assets seeking investments to overcome such capability gaps (Cui, Meyer, \& Hu, 2014; Rudy, Miller, \& Wang, 2016).

\section{Articles in the Special Issue}

The five articles in this special issue draw from a variety of theoretical perspectives, employ different research methods and different approaches to measure CPC. They examine domestic and international firms across different institutional contexts to advance our understanding of the role of CPC in global strategy. Table 3 provides a summary of the articles.

$$
\text { [place Table } 3 \text { about here] }
$$

Focusing on MNCs' legitimization strategy through building CPC with the host country's elites, Bucheli and Salvaj (2018) examine the operations of Esso, Shell, and ITTCTC in Chile from 1932 to 1973 . Using a historical research method to analyze the evolution of the political scene and the political affiliations of MNE boards, they find that these firms' 
legitimacy was affected differently as the country underwent social, political, and economic changes. Their findings provide rich insights into the relations between MNCs and governments and their evolution over time. Further, the paper highlights how business history can contribute to contemporary theoretical discourses in global strategy research.

Albino-Pimentel, Anand, and Dussauge (2018) examine the effects of firm CPC on cross-border acquisition activities of French MNCs. Using mental model arguments of firms' decision makers - members of the top management team and board of directors - the authors assert that politically embedded decision makers favor foreign acquisitions, yet when they also have strong firm embeddedness, this preference is reduced. Rather than treating decision makers with political embeddedness as a homogenous group, this study distinguishes types of decision makers and their associated political and firm embeddedness. Thus, it refines the understanding of the varying impacts of the political connections of decision makers on firms' foreign acquisition strategies.

Chen, Li, and Fan (2018) investigate how and under which conditions CPC become most helpful for emerging MNCs expanding to institutionally distant countries. Employing a strategy tripod perspective-industry-based, resource-based, and institutional-based viewsthey use the fuzzy-set qualitative comparative analysis (fsQCA) research method. Their analysis considers how different types of configurations of firms' home and host CPC together with resource and industry factors affect firms' decision to locate their international ventures in high- or low-distance foreign countries. The combination of the strategy tripod perspective and the fsQCA method enables the study to shed new light on the conditions under which CPC are best suited to address institutional barriers when emerging MNCs internationalize.

Drawing on social exchange theory, Liu, Yang, and Augustine (2018) examine how the value of CPC on firm performance is influenced by the proself engagement (take activities) and prosocial engagement (give activities) of the firm and institutional development of the country. Focusing on the Chinese context, they conduct a two-study examination, using different samples and variables over different study periods to examine the same hypotheses. Both studies find similar results on the relationships between CPC and firm performance. Highlighting the importance of processes of social exchange via firms' proself and prosocial 
engagement, the study advances our understanding on how a country's institutional development affects the value of CPC for firm performance.

Brown, Yaşar, and Rasheed (2018) draw on an institutional perspective to investigate how country-level characteristics influence the propensity of corporate political activity (CPA) by foreign firms in the USA. The authors go beyond the typical examination of the firm- and industry-level predictors of domestic firms' CPA. They focus on cultural-cognitive, normative, and regulative characteristics of the foreign firms' home country environments to explain these firms' willingness to engage in CPA in the USA. Their study demonstrates the importance of using institutional characteristics to explain foreign firms' non-market strategies, thereby providing new insights on global competition in the non-market arena.

\section{Contextualizing CPC Research: A Focus on Political Systems}

Management scholars often aim at generalizable insights; that is, insights that can be presumed to hold true in most countries around the world. In practice, however, management is by construction socially embedded (Hofstede, 1993), such that generalizable insights often arise only at high levels of abstraction. Thus, the studies in this special issue, like most of the reviewed literature, empirically investigate single national contexts, and are to some degree driven by an emic perspective that, on its own, provides little evidence on general insights. Few studies have explored aspects of the impact of national-level moderators on aspects of CPC in multi-country datasets (e.g. Estrin et al., 2016; He, Eden, \& Hitt, 2016; Hillman \& Wan, 2005). However, national context, especially political systems, are key to understanding how CPC are developed and deployed.

\section{Political systems and institutions as moderators}

Many aspects of a national economy have been shown to influence firm behavior. Management scholars traditionally focus on culture (e.g. Hofstede, 1993; Stahl \& Tung, 2015 ) and economic institutions (Kostova \& Marano, 2018; Meyer \& Peng, 2016). With respect to $\mathrm{CPC}$, in addition, particularly important is the political system within which business and government agents interact (Hillman \& Keim, 1995; Hillman \& Wan, 2005; Sun et al., 2012). Political systems influence for example which individuals can act as 
intermediaries in CPC on either side (business or government), the types of interactions between such individuals that are considered legal and legitimate, and the effectiveness of different types of interactions in influencing behaviors. These variations in political systems affect strategies of developing and deploying CPC.

Variations emerge at multiple levels. First, political systems vary between autocratic and democratic. In autocratic systems, power is concentrated in the hands of an autocratic leader, and effective $\mathrm{CPC}$ would have to connect to this leader or people close to the leader. However, when autocratic regimes change, $\mathrm{CPC}$ with the leader may turn into liabilities. For example, studies in Indonesia have shown a sharp depreciation of the value of CPC after the fall of the Suharto presidency (Dielemann, 2009; Leuz \& Oberholzer-Gee, 2006). In democratic regimes, change between political parties is more common, but even so, scholars have found that company performance can be affected by the electoral success of parties they are associated with in the USA (Goldman et al., 2009) and in Korea (Siegel, 2007). Consequently, businesses may develop hedging strategies of associating with multiple potentially influential political agents (Dieleman \& Boddewyn, 2012; Zhu \& Chung, 2014).

Second, democratic systems are governed through different electoral systems, which determine how individuals are selected into positions of power, and thus how businesses may develop CPC with people in such positions. For example, in first-past-the-post election systems (like the USA or the UK), engagement in local constituencies of specific candidates or campaign donations to such candidates may be effective in influencing law-making processes. In systems of proportional representation (as in most of continental Europe), political parties are relatively more important vis-à-vis individual members of parliament. Thus, CPC are likely to be more effective if they link to decision makers in political parties or influence the public opinion that parties aim to align with. Moreover, presidential systems (such as the USA, France or Korea) have more concentrated power than parliamentary systems (such as Germany, the UK or India), where the head of government can be replaced by parliament at any time. Thus, CPC may focus more on the president's personal network of advisors in a presidential system, and on parliament and political parties in a parliamentary system. However, at this time, we lack empirical evidence on these suggested variations. 
Third, the legal system and specific regulations determine which forms of interaction between business and political actors are legal. Three examples highlight this point:

- In many countries, private individuals and firms can make financial payments (often called 'donations') to political parties, interest groups or even individual candidates. Such payments are usually subject to campaign finance regulations that may require public transparency of such payments, or impose caps on donations by any individual contributor. Across countries, this boundary between legitimate engagement with political actors through political donations and illegal corruption varies considerably. For example, in the USA campaign donations face few constraints but are subject to public disclosure and thus are commonly used as a proxy in CPC research (Bonica 2016; Brown et al., 2018; Christensen, Dhaliwal, Boivie \& Graffin, 2015). Elsewhere, constraints apply, especially with respect to foreigners, which include MNEs. Thus, MNEs may not be able to build CPC by financially supporting political actors in foreign countries, and would likely seek other influence channels.

- Rules on lobbying may regulate how private individuals and firms may access politicians. Lobbyists aim to present their views directly to decision makers such as officials drafting legal texts or parliamentarians voting on laws. They may share relevant information in return for the opportunity to speak directly to the decision makers. For example, Kautto's (2009) case study of Nokia illustrates how an MNE used multiple channels to build and exploits CPC in the European Union to influence what later became known as the 'Directive on the Eco-Design of Energy-using Products'. Regulations affect which channels of influencing such government agents are legal and legitimate. For example, the European Union has official forums where businesses and other interest groups meet with political agents, and which complement informal channels (Dur \& Mateo, 2012; Kluver, 2013). In other places, lobbyists have access to the buildings where parliamentarians or government officials work, perhaps conditional on being registered as a lobbyist. Yet, regulations of these interactions vary widely. For example, payment for private meetings with key decision makers is usually illegal, but the laws or their enforcement may contain loopholes. 
- Rules regarding conflict of interest may constrain individuals moving between the private and public sector of a country. For example, are politicians that step down from political office allowed to work in companies they used to regulate? Are government officials after retirement allowed to hold corporate board positions? Such movement of individuals are common in many countries. For example, in the USA, former government officers are sought after for corporate boards (Lester et al. 2008), while in China, boards often include individuals that also serve in the national party congress or the Chinese People's Political Consultative Committee (e.g. Li et al., 2018; Liang, Ren, \& Sun, 2015; Zheng, et al., 2015). Scholars frequently use such movements of individuals to proxy the existence of CPC. The feasibility of such moves, and the potential contributions of such individuals depend on the formal and informal rules regarding these 'revolving doors' between business and government (Transparency International, 2011).

Fourth, in addition to formal rules, enforcement mechanisms and informal norms in a society affect the use of CPC. For example, some countries demand high levels of transparency on aspects of business-to-government interactions, which can increase public scrutiny and informal punishment of interactions that are legal but not considered legitimate. Moreover, corruption represents an illegal way to build CPC, but in some contexts, risk of detection and punishment are sufficiently low that some businesses consider it an effective strategy (Lambsdorff, 2002). Elsewhere, high level CPC may be an effective means to protect a firm from corrupt demands of low-level officials.

Fifth, the effectiveness of the executive branch of government varies across countries; for example, with respect to the extent of agency conflicts between layers of the hierarchy in the public sector. This influences, for example, the monitoring of SOEs and thus the alignment of SOE strategies with higher-level political objectives. For example, Estrin et al. (2016) argue that countries with more developed institutions also have fewer inefficiencies in the governance of SOEs, and hence, SOE internationalization strategies are more similar to those of private firms. More generally, we would expect that the better managed the executive branch of government, the less effective are CPC with low level officials in influencing governmental resource allocation or implementation of regulations. 
Sixth, the focus of CPC varies with the centralization of power. In federal systems, power is delegated to provinces or states in a nation (as in the USA, Australia and Germany). Even in China, provinces wield considerable power in interpreting and applying regulation issues by the national authorities ( $\mathrm{Li}$ et al., 2014). Some power is even delegated to municipal authorities; for example, to attain planning permissions for construction projects, businesses often need to engage with political agents at local levels. Thus, firms may need to develop $\mathrm{CPC}$ at the appropriate level of government to influence regulations of concern to them. Authority may also be delegated to independent regulatory authorities that have some degree of autonomy in interpreting relevant legislation (e.g. environmental protection agencies or competition authorities).

Overall, our brief discussion of political systems generated several suggestions of contingencies influencing CPC. Yet, empirical evidence is scarce; most of our discussion could only present propositions. Thus, need for further research is evident.

\section{Contextualized development of measurements}

Cross-national variations affect not only the mechanisms through which CPC are created and exploited, but the validity of scales used to proxy or measure CPC, an important concern for research agendas spanning multiple contexts (Farh et al., 2006). The selection of papers in this special issue are indicative of this challenge. Authors use a variety of different measures to operationalize the construct of $\mathrm{CPC}$, and we propose that most of these measures would be of limited value if applied in another context.

Albino-Pimentel et al. (2018) argue that the alumni of the École Nationale d'Administration (ENA) share important network relationships throughout their professional lives, and therefore an alumnus of the ENA in the top management team is a good proxy for the presence of CPC. In few other countries do business and government elites graduate from the same school(s) such that ties to that school become a good proxy for CPC.

Brown et al. (2018) proxy CPA by foreign MNEs in the USA by political donations. This proxy seems appropriate in the USA, but it makes a number of assumptions that may not apply elsewhere: direct donations to political agents are legal, such donations are transparently recorded, and political actors consider their donors when making political 
decisions. Where corporate donations especially by non-nationals to political actors are capped or otherwise constrained such a proxy would not be appropriate.

Chen et al. (2018) and Liu et al. (2018) use a survey-based measure based on Peng and Luo (2000) to proxy CPC. This three-item measure is based on the statement 'Our firm has maintained good relationships with officials in a) the central government, b) local governments, c) regulatory and supporting institutions, such as tax bureaus, commercial administration bureaus, and finance bureaus'. This measure has been very popular in Chinabased research (e.g. Cao, Simsek \& Jansen, 2015; Cui et al., 2017). Yet, if applied elsewhere, at a minimum, the institutions mentioned would have to be amended, and other actors such as elected members of parliament would have to be included.

Hence, each of these measures appears to be valid in the given study and enables valid scholarly insights. The authors may also argue that their theoretical arguments would be generalizable beyond the specific context by carefully reflecting over similarities and differences across contexts. However, any translation to other contexts to derive management or policy implications needs to carefully disentangle context-specific influences.

\section{Future Research}

Contextualization emphasizes the boundaries of our understanding of the phenomenon under research. This concerns both the design of studies and the interpretation of research findings. Contextualization is particularly important for international business research because crosscountry differences are at the core of this field and define its domain (Meyer, 2015; Michailova, 2011; Teagarden, von Glinow, \& Mellahi, 2017). Our review of CPC in international business has made us aware of many contextual influences. Yet, we also have become aware that explicit consideration of contextual boundary conditions is still underdeveloped. We therefore advocate future research to make contextual influences on their research more explicit, and thereby to develop more clearly the contingencies under which CPC evolve, are used, and contribute to firm performance around the world.

First, we suggest careful consideration of generalizable insights from CPC research in single-country contexts, and we encourage researchers to examine the contextual contingencies of $\mathrm{CPC}$ by conducting multi-country comparative research. A large share of 
recent CPC research relies on evidence from single-country contexts, as illustrated above. These single-country studies generate valuable insights, but for businesses spanning multiple countries, such as foreign direct investment and international alliances, the usefulness of these insights can be limited. Thus, we need more studies that context-sensitively replicate studies across countries, and test proposed country-level contingencies on CPC using multicountry datasets.

Second, comparative research on CPC should move beyond broad categories of political systems, such as autocracy vs. democracy, and pay more attention to idiosyncrasies within each category, as discussed above. To better understand such idiosyncrasies, business researchers should further engage with the political science literature. For example, depending on the regime's time horizon, autocratic states can vary substantially on their priorities and attitudes toward foreign investors (Moon, 2015), thus influencing how foreign investors align their CPC activities with the incentives of the autocratic states. Overall, global strategy research can benefit from deeper engagement with the political science literature in identifying strategies for MNEs to engage with local stakeholders.

Third, firms may alternate or combine CPC and other non-market strategies in different contexts. The distinction and, more importantly, interaction between CPC and other nonmarket strategies deserve further research attention. For example, what is the relationship between corporate social and political activities? Recent studies in China and India suggest that donation to social causes of concern to political leaders may help building political good will (Mithani, 2017; Zhang \& Luo, 2013). In this special issue, Liu et al. (2018) find moderating effects of social engagement on the performance impact of CPC. Thus, CPC and corporate social responsibility appear to be complements in some contexts, but interact in more complex ways elsewhere. Future research may aim to shed more light on these interactions under different environmental conditions.

Fourth, the characteristics that make individuals carriers of CPC in companies and in government agencies vary considerably. In some studies, it is former politicians in business; in others, it is business persons with personal ties to government officials or in a formal role in a political agency or in parliament. It would be interesting to explore in deeper comparative analysis the strategies that MNEs use to engage with governments. For example, 
what contextual influences determine through which intermediaries MNEs approach political actors in host countries?

Fifth, many of the studies focus on how MNEs use CPCs in host countries, contingent on the characteristics of the MNE and its home country. However, there are few studies that compare in a given host context how MNE subsidiaries differ from local firms in how they build and exploit CPC. Given the legitimacy challenges that foreign MNEs potentially face (Meyer et al., 2014; Siegel, 2007; Stevens \& Newenham-Kahindi, 2017), some political activity that is considered legitimate for local firms may not be legitimate for foreign firms. In addition to the political system, informal institutions such as social norms and cultural cognitive factors are likely to represent important boundary conditions for theories of CPC. Future research may explore the interaction and configuration of formal institutions, informal institutions, and firms' CPC to shed light on the contextual fit of CPC for different business actors within or across contexts. Such a holistic approach may generate novel insights into the operational realities faced by MNEs; for example, by applying a configurational lens to theorize and empirically investigate the contextual contingencies of CPC.

\section{Conclusions}

Our critical review of the CPC literature has outlined the research progress made on CPC, noting the limitations in this literature. In particular, we have explored contextual contingencies on the development and deployment of CPC by MNEs, and hence the challenges to contextualize research while developing general theory. On this basis, we suggest future directions of CPC research that emphasize context in the design of studies and in the interpretation of research findings. 


\section{References}

Acemoglu, F., Johnson, S., Kermani, A., Kwak, J. \& Milton, T. 2016. The value of connections in turbulent times, Journal of Financial Economics, 121(2): 368-391.

Albino-Pimentel J, Anand R, Dussauge P. 2018. How do firm political connections impact foreign acquisitions? The effects of decision makers' political and firm embeddedness. Global Strategy Journal. https://doi.org/10.1002/gsj.1189

Benito, R.G.R., Rygh, A. \& Lunnan, R. 2016. The benefits of internationalization for stateowned enterprises, Global Strategy Journal, 6(4): 269-288.

Boddewyn JJ. 1988. Political aspects of MNE theory. Journal of International Business Studies 19(3): 341-363.

Boddewyn JJ. 2016. International business-government relations research 1945-2015: concepts, typologies, theories and methodologies. Journal of World Business 51(1): 10-22.

Bonica A. 2016. Avenues of influence: on the political expenditures of corporations and their directors and executives. Business and Politics 18(4): 367-394.

Brockman P, Rui OM, Zou H. 2013. Institutions and the performance of politically connected M\&As. Journal of International Business Studies 44(8): 833-852.

Brown LW, Yaşar M, Rasheed AA. 2018. Predictors of foreign corporate political activities in United States politics. Global Strategy Journal. https://doi.org/10.1002/gsj.1185

Bucheli M, Salvaj E. 2018. Political connections, the liability of foreignness, and legitimacy: a business historical analysis of multinationals' strategies in Chile. Global Strategy Journal. https://doi.org/10.1002/gsj.1195

Buckley PJ, Clegg J, Tan H. 2006. Cultural awareness in knowledge transfer to China-The role of guanxi and mianzi. Journal of World Business 41(3): 275-288.

Calluzzo P, Dong GN, Godsell D. 2017. Sovereign wealth fund investments and the US political process. Journal of International Business Studies 48(2): 222-243.

Cao Q, Simsek Z, Jansen JJ. 2015. CEO social capital and entrepreneurial orientation of the firm: bonding and bridging effects. Journal of Management 41(7): 1957-1981.

Chen D, Paik Y, Park SH. 2010. Host-country policies and MNE management control in IJVs: evidence from China. Journal of International Business Studies, 41(3): 526-537.

Chen L, Li Y, Fan D. 2018. How do emerging multinationals configure political connections across institutional contexts? Global Strategy Journal. https://doi.org/10.1002/gsj.1187

Chen R, Cui L, Li S, Rolfe R. 2017. Acquisition or greenfield entry into Africa? Responding to institutional dynamics in an emerging continent. Global Strategy Journal 7(2): 212-230.

Child J, Marinova S. 2014. The role of contextual combinations in the globalization of Chinese firms. Management and Organization Review, 10(3): 347-371.

Choudhury P, Khanna T. 2014. Toward resource independence-Why state-owned entities become multinationals: an empirical study of India's public R\&D laboratories. Journal of International Business Studies 45(8): 943-960. 
Christensen DM, Dhaliwal DS, Boivie S, Graffin SD. 2015. Top management conservatism and corporate risk strategies: evidence from managers' personal orientation and corporate tax avoidance. Strategic Management Journal 36(12): 1918-1938.

Cuervo-Cazurra A, Genc M. 2008. Transforming disadvantages into advantages: developingcountry MNEs in the least developed countries. Journal of International Business Studies, 39(6): 957-979.

Cuervo-Cazurra A, Inkpen A, Musacchio A, Ramaswamy K. 2014. Governments as owners: state-owned multinational companies. Journal of International Business Studies, 45: 919-942.

Cui L, Fan D, Guo F, Fan Y, 2017. Explicating the relationship of entrepreneurial orientation and firm performance: underlying mechanisms in the context of an emerging market. Industrial Marketing Management. https://doi.org/10.1016/j.indmarman.2017.11.003.

Cui L, Jiang F. 2012. State ownership effect on firms' FDI ownership decisions under institutional pressure: a study of Chinese outward-investing firms. Journal of International Business Studies 43(3): 264-284.

Cui L, Meyer KE, Hu H. 2014. What drives firms' intent to seek strategic assets by foreign direct investment? A study of emerging economy firms. Journal of World Business 49(4): 488-501.

Dahan, N, Doh, J, Guay, T. 2006. The role of multinational corporations in transnational institution building: a policy network perspective. Human Relations 59(11): 1571-1600.

del Sol P, Kogan J. 2007. Regional competitive advantage based on pioneering economic reforms: the case of Chilean FDI. Journal of International Business Studies 38(6): 901-927.

Dieleman M. 2009. Shock-imprinting: external shocks and ethnic Chinese business groups in Indonesia. Asia Pacific Journal of Management 27(3): 481-502.

Dieleman M, Boddewyn J. 2012. Using organization structure to buffer political ties in emerging markets: a case study. Organization Studies 33(1): 71-95.

DiMaggio PJ, Powell WW. 1983. The iron cage revisited: institutional isomorphism and collective rationality in organizational fields. American Sociological Review 48(2): 147-160.

Doh JP, Lawton TC, Rajwani, T. 2012. Advancing nonmarket strategy research: institutional perspectives in a changing world. Academy of Management Perspectives 26(3): 22-39.

Doh JP, Lucea R. 2013. So close yet so far: integrating global strategy and nonmarket research. Global Strategy Journal 3(2): 171-194.

Duanmu JL. 2012. Firm heterogeneity and location choice of Chinese multinational enterprises (MNEs). Journal of World Business 47(1): 64-72.

Dur A, Mateo G. 2012. Who lobbies the European Union? Journal of European Public Policy 19: 969-987.

Eden L, Lenway S, Schuler R. 2005. From the obsolescing bargain to the political bargaining model. In Multinational Enterprises and Government Relations, Grosse R (ed.). Cambridge University Press: Cambridge, U.K; 251-272. 
Estrin S, Meyer KE, Nielsen BB, Nielsen, ST. 2016. Home country institutions and the internationalization of state owned enterprises: a cross-country analysis. Journal of World Business 51(2): 294-307.

Faccio, M. 2006. Politically connected firms, American Economics Review, 91(4): 369-386.

Farh L, Cannella AA, Lee C. 2006. Approaches to scale development in Chinese management research. Management and Organization Review 2(3): 301-318.

Fernández-Méndez L, García-Canal E, Guillén M. 2018. Domestic political connections and international expansion: it's not only 'who you know' that matters. Journal of World Business, advance online. https://doi.org/10.1016/j.jwb.2018.03.006

Fisman R. 2001. Estimating the value of political connections. American Economic Review 91(4): 1095-1102.

Frynas J, Mellahi K, Pigman GA. 2006. First mover advantages in international business and firm-specific political resources. Strategic Management Journal 27(4): 321-345.

Goldman E, Rocholl J, So J. 2009. Do politically connected boards affect firm value? Review of Financial Studies 22(6): 2331-1360.

Grosse R (ed.). 2004. International Business and Government Relations in the 21st Century. Cambridge University Press: Cambridge.

Hansen WL, Mitchell NJ. 2000. Disaggregating and explaining corporate political activity: domestic and foreign corporations in national politics. American Political Science Review 94(4): 891-903.

He X, Eden L, Hitt MA. 2016. Shared governance: institutional investors as a counterbalance to the state in state owned multinationals. Journal of International Management 22(2): 115130 .

Heidenreich S, Mohr A, Puck J. 2015. Political strategies, entrepreneurial overconfidence and foreign direct investment in developing countries. Journal of World Business 50(4): 793-803.

Hennart JF, Sheng HH, Carrera Jr JM. 2017. Openness, international champions, and the internationalization of multilatinas. Journal of World Business 52(4): 518-532.

Hillman, A. 2005. Politicians on the board of directors: do connections affect the bottom line? Journal of Management 31(3): 464-481.

Hillman A, Keim G. 1995. International variation in the business-government interface: institutional and organizational considerations. Academy of Management Review 20(1): 193214.

Hillman A, Wan WP. 2005. The determinants of MNE subsidiaries' political strategies: evidence of institutional duality. Journal of International Business Studies 36(3): 322-340.

Hofstede G. 1993. Cultural constraints in management theories. Academy of Management Executive 7(1): 81-94.

Holburn GLF, van den Bergh RG. 2008. Making friends in hostile environments: political strategy in regulated industries. Academy of Management Review 33(2): 521-540. 
Holburn GLF, Zelner BA. 2010. Political capabilities, policy risk, and international investment strategy: evidence from the global electric power generation industry. Strategic Management Journal 31(12): 1290-1315.

Hu HW, Cui L. 2014. Outward foreign direct investment of publicly listed firms from China: a corporate governance perspective. International Business Review 23(4): 750-760.

Huang Y, Xie E, Li Y, Reddy KS. 2017. Does state ownership facilitate outward FDI of Chinese SOEs? Institutional development, market competition, and the logic of interdependence between governments and SOEs. International Business Review 26(1): 176188.

Jensen, NM. 2008. Nation-states and the Multinational Corporation: A Political Economy of Foreign Direct Investment. Princeton University Press: New Jersey.

Jia N. 2018. The 'make and/or buy' decisions of corporate political lobbying: integrating the economic efficiency and legitimacy perspectives. Academy of Management Review 43(2): $307-326$.

Kautto P. 2009. Nokia as an environmental policy actor. Journal of Common Market Studies 47: $103-125$.

King MR. 2015. Political bargaining and multinational bank bailouts. Journal of International Business Studies 46(2): 206-222.

Kluver H. 2013. Lobbying as a collective enterprise. Journal of European Public Policy 20: 59-76.

Kobrin S. 1987. Testing the bargaining hypothesis in the manufacturing sector in developing countries. International Organization 41(4): 609-638.

Kostova T, Marano V. 2018. Institutional theory perspectives on emerging economies. In Oxford Handbook of Managing in Emerging Markets, Grosse, R, Meyer, KE (eds). In press.

Lambsdorff, JG. 2002. Making corrupt deals: contracting in the shadow of the law. Journal of Economic Behavior and Organization 48(3): 221-241.

Lester RH, Hillman A, Zardkoohi A, Cannella AA. 2008. Former government officials as outside directors: the role of human and social capital. Academy of Management Journal 51(5): 999-1013.

Leung K. 2009. Never the twain shall meet? Integrating Chinese and western management research. Management and Organization Research 5(1): 121-129.

Leuz C, Oberholzer-Gee F. 2006. Political relationships, global financing, and corporate transparency: evidence from Indonesia. Journal of Financial Economics 81(2): 411-439.

Li J, Meyer KE, Zhang H, Ding Y. 2018. Diplomatic and corporate networks: bridges to foreign locations. Journal of International Business Studies. https://doi.org/10.1057/s41267$\underline{017-0098-4}$

Li MH, Cui L, Lu J. 2014. Varieties in state capitalism: outward FDI strategies of central and local state-owned enterprises from emerging economy countries. In State-Owned Multinationals. Palgrave Macmillan: Cham; 175-210. 
Li J, Newenham-Kahindi A, Shapiro D, Chen V. 2013. The two-tier bargaining model revisited: theory and evidence from China's natural resource investments in Africa. Global Strategy Journal 3: 300-321.

Li J, Xia J, Lin Z. 2017. Cross-border acquisitions by state-owned firms: how do legitimacy concerns affect the completion and duration of their acquisitions? Strategic Management Journal 38(9): 1915-1934.

Li JJ, Zhou KZ, Shao AT. 2009. Competitive position, managerial ties, and profitability of foreign firms in China: an interactive perspective. Journal of International Business Studies 40(2): 339-352.

Liang H, Ren B, Sun SL. 2015. An anatomy of state control in the globalization of stateowned enterprises. Journal of International Business Studies 46(2): 223-240.

Liu H, Yang JY, Augustine D. 2018. Political ties and firm performance: the effects of proself and prosocial engagement and institutional development. Global Strategy Journal. https://doi.org/10.1002/gsj.1194

Liu X, Wang C, Wei Y. 2009. Do local manufacturing firms benefit from transactional linkages with multinational enterprises in China? Journal of International Business Studies 40(7): 1113-1130.

Luo Y. 2004. A coopetition perspective of MNC-host government relations. Journal of International Management 10(4): 431-451.

Ma X, Delios A. 2010. Host-country headquarters and an MNE's subsequent within-country diversifications. Journal of International Business Studies 41(3): 517-525.

Marquis C, Raynard M. 2015. Institutional strategies in emerging markets. The Academy of Management Annals 9(1): 291-335.

Mbalyohere C, Lawton T, Boojihawon R, Viney H. 2017. Corporate political activity and location-based advantage: MNE responses to institutional transformation in Uganda's electricity industry. Journal of World Business 52(6): 743-759.

Meyer CB, Altenborg E. 2008. Incompatible strategies in international mergers: the failed merger between Telia and Telenor. Journal of International Business Studies 39(3): 508-525.

Meyer KE. 2015. Context in management research in emerging economies. Management and Organization Review 11(3): 369-377.

Meyer KE, Ding Y, Li J, Zhang H. 2014. Overcoming distrust: how state-owned enterprises adapt their foreign entries to institutional pressures abroad. Journal of International Business Studies 45(8): 1005-1028.

Meyer KE, Grosse R. 2018. Introduction to managing in emerging markets. In Oxford Handbook of Managing in Emerging Markets, Grosse, R, Meyer, KE. In press.

Meyer KE, Peng MW. 2016. Theoretical foundations of emerging economy research. Journal of International Business Studies 47(1): 3-22.

Meyer KE, Mudambi R, Narula R. 2011. Multinational enterprises and local contexts. Journal of Management Studies 48(2): 235-253. 
Michailova S. 2011. Contextualizing in international business research: why do we need more of it and how can we be better at it? Scandinavian Journal of Management 27(1): 129139.

Mithani, MA. 2017. Liability of foreignness, natural disasters, and corporate philanthropy. Journal of International Business Studies 48(8): 941-963.

Moon, C. 2015. Foreign direct investment, commitment institutions, and time horizon: how some autocrats do better than others. International Studies Quarterly 59(2): 344-356.

Morck R., Yeung B, Zhao M. 2008. Perspectives on China's outward foreign direct investment. Journal of International Business Studies 39(3): 337-350.

Morris MW, Leung K, Ames D, Lickel B. 1999. Views from inside and outside: integrating emic and etic insights about culture and justice judgement. Academy of Management Review 24(4): 781-796.

Müllner J, Puck J. 2018. Towards a holistic framework of MNE-state bargaining: a formal model and case-based analysis. Journal of World Business 53(1): 15-26.

Murtha TP, Lenway SA. 1994. Country capabilities and the strategic state: how national political institutions affect multinational corporations' strategies. Strategic Management Journal 15(S2): 113-129.

Oliver C, Holzinger I. 2008. The effectiveness of strategic political management: a dynamic capabilities framework. Academy of Management Review 33(2): 496-520.

Peng MW, Luo YD. 2000. Managerial ties and firm performance in a transition economy: the nature of a micro-macro link. Academy of Management Journal 43(3): 486-501.

Pfeffer J, Salancik GR. 1978. The External Control of Organizations: A Resource Dependence Perspective. Harper \& Row: New York.

Pinto CF, Ferreira MP, Falaster C, Fleury MTL, Fleury A. 2017. Ownership in cross-border acquisitions and the role of government support. Journal of World Business 52(4): 533-545.

Puck JF, Rogers H, Mohr AT. 2013. Flying under the radar: foreign firm visibility and the efficacy of political strategies in emerging economies. International Business Review 22(6): 1021-1033.

Ramamurti R. 2000. Risks and rewards in the globalization of telecommunications in emerging economies. Journal of World Business 35(2): 149-170.

Ramamurti R. 2001. The obsolescing ‘bargaining model'? MNC-host developing country relations revisited. Journal of International Business Studies 32(1): 23-39.

Rizopoulos YA, Sergakis DE. 2010. MNEs and policy networks: institutional embeddedness and strategic choice. Journal of World Business 45(3): 250-256.

Rudy BC, Miller SR, Wang D. 2016. Revisiting FDI strategies and the flow of firm-specific advantages: a focus on state-owned enterprises. Global Strategy Journal 6(1): 69-78.

Sheng SB, Zhou KZ, Li JJ. 2011. The effects of business and political ties on firm performance: evidence from China. Journal of Marketing 75(1): 1-15. 
Shirodkar V, Mohr AT. 2015. Resource tangibility and foreign firms' corporate political strategies in emerging economies: evidence from India. Management International Review 55(6): 801-825.

Siegel J. 2007. Contingent political capital and international alliances: evidence from South Korea. Administrative Science Quarterly 52: 621-666.

Stahl GK, Tung R. 2015. Towards a more balanced treatment of culture in international business studies: the need for positive cross-cultural scholarship. Journal of International Business Studies 46(4): 391-414.

Stevens C, Newenham-Kahindi A. 2017. Legitimacy spillovers and political risk: the case of FDI in the East African Community. Global Strategy Journal 7(1): 10-35.

Stopford JM, Strange S. 1991. Rival States, Rival Firms. Cambridge University Press: Cambridge, U.K.

Sun P. 2018. Corporate political ties. In Oxford Handbook of Managing in Emerging Markets, Grosse, R, Meyer, KE. In press.

Sun P, Mellahi K, Wright M. 2012. The contingent value of corporate political ties. Academy of Management Perspectives 26(3): 68-82.

Teagarden MB, von Glinow MA, Mellahi K. 2017. Contextualizing international business research: enhancing rigor and relevance. Journal of World Business 53: 303-306.

Transparency International. 2011. Cabs for hire? Fixing the revolving door between government and business. Report, available at:

www.transparency.org/files/content/pressrelease/20110517_UK_Revolving_Door_EN.pdf (accessed June 8, 2018).

Tse CH, Yu L, Zhu J. 2017. A multimediation model of learning by exporting: analysis of export-induced productivity gains. Journal of Management 43(7): 2118-2146.

Whetten D. 2009. An examination of the interface between context and theory applied to the study of Chinese organizations. Management and Organization Review 5(1): 29-55.

White III GO, Boddewyn JJ, Galang RMN. 2015. Legal system contingencies as determinants of political tie intensity by wholly owned foreign subsidiaries: insights from the Philippines. Journal of World Business 50(2): 342-356.

Wöcke A, Moodley T. 2015. Corporate political strategy and liability of foreignness: similarities and differences between local and foreign firms in the South African health sector. International Business Review 24(4): 700-709.

Wu J, Zhao H. 2015. The dual effects of state ownership on export activities of emerging market firms: an inducement-constraint perspective. Management International Review 55(3): 421-451.

Wu J, Wang C, Hong J, Piperopoulos P, Zhuo S. 2016. Internationalization and innovation performance of emerging market enterprises: the role of host-country institutional development. Journal of World Business 51(2): 251-263. 
Xia J, Ma X, Lu JW, Yiu DW. 2014. Outward foreign direct investment by emerging market firms: a resource dependence logic. Strategic Management Journal 35(9): 1343-1363.

Yamakawa Y, Peng MW, Deeds DL. 2008. What drives new ventures to internationalize from emerging to developed economies? Entrepreneurship Theory and Practice, 32(1): 5982.

Zhang JJ, Luo XWR. 2013. Dared to care: organizational vulnerability, institutional logics, and MNCs' social responsiveness in emerging markets. Organization Science 24(6): 17421764.

Zhang X, Ma X, Wang Y, Li X, Huo D. 2016. What drives the internationalization of Chinese SMEs? The joint effects of international entrepreneurship characteristics, network ties, and firm ownership. International Business Review 25(2): 522-534.

Zheng W, Singh K, Chung CN. 2017. Ties to unbind: political ties and firm sell-offs during institutional transition. Journal of Management 43(7): 2005-2036.

Zheng W, Singh K, Mitchell W. 2015. Buffering and enabling: the impact of interlocking political ties on firm survival and sales growth. Strategic Management Journal 36(11): 16151636.

Yan JZ, Chang SJ. 2018. The contingent effects of political strategies on firm performance: a political network perspective. Strategic Management Journal.

https://doi.org/10.1002/smj.2908

Yang W, Meyer KE. 2018. How does ownership influence business growth? A competitive dynamics perspective. International Business Review.

https://doi.org/10.1016/j.ibusrev.2018.02.009

Zhu H, Chung CN. 2014. Portfolio of political ties and business group strategy in emerging economies: evidence from Taiwan. Administrative Science Quarterly 59(4): 599-638.

Zou H, Adams MB. 2008. Corporate ownership, equity risk and returns in the People's Republic of China. Journal of International Business Studies 39(7): 1149-1168. 
Table 1 CPC Research in International Business Journals ${ }^{1}$

\begin{tabular}{|c|c|c|c|c|c|c|c|}
\hline & $\begin{array}{l}\text { Journal of } \\
\text { International } \\
\text { Business } \\
\text { Studies }\end{array}$ & $\begin{array}{l}\text { Journal of } \\
\text { World } \\
\text { Business }\end{array}$ & $\begin{array}{l}\text { Global } \\
\text { Strategy } \\
\text { Journal }\end{array}$ & $\begin{array}{l}\text { International } \\
\text { Business } \\
\text { Review }\end{array}$ & $\begin{array}{l}\text { Management } \\
\text { International } \\
\text { Review }\end{array}$ & $\begin{array}{l}\text { Journal of } \\
\text { International } \\
\text { Management }\end{array}$ & Total \\
\hline $2015-2018^{2}$ & 10 & 15 & 5 & 11 & 7 & 3 & 51 \\
\hline 2010-2014 & 15 & 3 & 1 & 7 & 3 & 2 & 31 \\
\hline $2005-2009$ & 9 & 1 & n.a. ${ }^{3}$ & 1 & 1 & 2 & 14 \\
\hline $2000-2004$ & 5 & 3 & n.a. ${ }^{3}$ & 1 & $0^{4}$ & 1 & 10 \\
\hline 1995-1999 & 3 & 0 & n.a. ${ }^{3}$ & 0 & $0^{4}$ & 0 & 3 \\
\hline 1990-1994 & 2 & 0 & n.a. ${ }^{3}$ & 0 & $0^{4}$ & n.a. ${ }^{3}$ & 2 \\
\hline Total & 44 & 22 & 6 & 20 & 11 & 8 & 111 \\
\hline
\end{tabular}

Notes:

1) Articles included in review based on content search of article title, keywords, and abstract on keywords including 'political connection/tie/lobby/strategy/behavior/relation', 'government connection/tie/relation', 'state connection/tie/ownership/owned', 'administrative connection/tie', 'institutional connection/tie';

2) Articles published online by 10 May 2018;

3) Not applicable (GSJ started in 2011; JIM in 1995);

4) Searched on titles only. 
Table 2 Theoretical Perspectives on Corporate Political Connections (CPC)

\begin{tabular}{|c|c|c|c|}
\hline Theoretical lens & Core theoretical arguments & Exemplar studies & $\begin{array}{l}\text { Contribution in this } \\
\text { special issue }\end{array}$ \\
\hline $\begin{array}{l}\text { New institutional } \\
\text { economics }\end{array}$ & $\begin{array}{l}\text { Incentives created by institutions, notably } \\
\text { 'institutional voids', determine how firms develop } \\
\text { and exploit CPC }\end{array}$ & $\begin{array}{l}\text { White } \text { et al., } 2015 \\
\text { Chen } \text { et al., } 2017 \\
\text { Brockman } \text { et al., } 2013\end{array}$ & Chen, Li \& Fan \\
\hline $\begin{array}{l}\text { Neo-institutional } \\
\text { perspective }\end{array}$ & $\begin{array}{l}\text { CPC help attaining political and social legitimacy in } \\
\text { a given context, but may become a legitimacy } \\
\text { liability in a different context }\end{array}$ & $\begin{array}{l}\text { Hillman \& Wan, } 2005 \\
\text { Cui \& Jiang, } 2012 \\
\text { Meyer et al., } 2014 \\
\text { Li et al. } 2018 \\
\end{array}$ & $\begin{array}{l}\text { Brown, Yasar \& Rasheed } \\
\text { Bucheli \& Salvaj }\end{array}$ \\
\hline $\begin{array}{l}\text { Resource } \\
\text { dependence theory }\end{array}$ & $\begin{array}{l}\text { CPC help to absorb uncertainties in firms' resource } \\
\text { exchange with governments, and may motivate them } \\
\text { to diversify from political sources of resource supply }\end{array}$ & $\begin{array}{l}\text { Wu and Zhao, } 2015 \\
\text { Choudhury and Khanna, } 2014 \\
\text { Huang et al., } 2017\end{array}$ & Liu, Yang \& Augustine \\
\hline $\begin{array}{l}\text { Corporate } \\
\text { governance } \\
\text { perspective }\end{array}$ & $\begin{array}{l}\text { CPC position government as a shareholder or } \\
\text { stakeholder of the firm and thereby directly influence } \\
\text { strategic decision making performance }\end{array}$ & $\begin{array}{l}\text { Morck et al., } 2008 \\
\text { Zou \& Adams, } 2008 \\
\text { Hu \& Cui, } 2014 \\
\text { Estrin } \text { et al., } 2016\end{array}$ & $\begin{array}{l}\text { Albino-Pimentel, Anand \& } \\
\text { Dussauge }\end{array}$ \\
\hline $\begin{array}{l}\text { Resource and } \\
\text { learning perspectives }\end{array}$ & $\begin{array}{l}\text { CPC are a valuable resource and/or help accessing } \\
\text { critical resources, and thereby shape resource } \\
\text { accumulation and learning processes }\end{array}$ & $\begin{array}{l}\text { Cuervo-Cazurra \& Genc, } 2008 \\
\text { Liu } \text { et al., } 2009 \\
\text { Benito et al., } 2016 \\
\text { Wu et al., } 2016\end{array}$ & None \\
\hline $\begin{array}{l}\text { Political power } \\
\text { perspectives }\end{array}$ & $\begin{array}{l}\text { CPC shift the bargaining positions in negotiations } \\
\text { between business and government actors }\end{array}$ & $\begin{array}{l}\text { King } 2015 \\
\text { Calluzo et al., } 2017\end{array}$ & None \\
\hline
\end{tabular}


Table 3 Papers in This Special Issue

\begin{tabular}{|c|c|c|c|c|c|c|c|}
\hline & $\begin{array}{l}\text { Theoretical } \\
\text { relationship } \\
\text { examined }\end{array}$ & $\begin{array}{l}\text { Study } \\
\text { period }\end{array}$ & Sample & Data sources & $\begin{array}{l}\text { Operationalization } \\
\text { of CPC construct }\end{array}$ & $\begin{array}{l}\text { Political } \\
\text { forums }\end{array}$ & Key finding \\
\hline $\begin{array}{l}\text { Bucheli } \\
\text { and } \\
\text { Salvaj }\end{array}$ & $\begin{array}{l}\text { CPC on host } \\
\text { country } \\
\text { legitimacy } \\
\text { during } \\
\text { political } \\
\text { upheaval }\end{array}$ & $\begin{array}{l}1932- \\
1973\end{array}$ & $\begin{array}{l}\text { MNEs: } \\
\text { Esso, Shell, } \\
\text { and ITT- } \\
\text { CTC }\end{array}$ & $\begin{array}{l}\text { Corporate and } \\
\text { government archives }\end{array}$ & $\begin{array}{l}\text { Associations of } \\
\text { board members } \\
\text { with political } \\
\text { parties. }\end{array}$ & $\begin{array}{l}\text { Host- } \\
\text { Chile }\end{array}$ & $\begin{array}{l}\text { Unlike Esso and Shell, } \\
\text { ITT-CTC experienced } \\
\text { obsolescing political } \\
\text { legitimacy as the host } \\
\text { country's political regime } \\
\text { changed. }\end{array}$ \\
\hline $\begin{array}{l}\text { Albino- } \\
\text { Pimentel, } \\
\text { Anand } \\
\text { and } \\
\text { Dussage }\end{array}$ & $\begin{array}{l}\text { CPC affect } \\
\text { cross-border } \\
\text { acquisitions }\end{array}$ & $\begin{array}{l}2009- \\
2014\end{array}$ & $\begin{array}{l}312 \text { publicly } \\
\text { listed } \\
\text { French } \\
\text { firms }\end{array}$ & $\begin{array}{l}\text { Bureau } \\
\text { van Dijk (BvD) } \\
\text { databases and ENA } \\
\text { Yearbooks }\end{array}$ & $\begin{array}{l}\text { Board members are } \\
\text { alumni of École } \\
\text { National } \\
\text { d'Adminstration }\end{array}$ & $\begin{array}{l}\text { Home- } \\
\text { France }\end{array}$ & $\begin{array}{l}\text { Foreign acquisitions are } \\
\text { primarily driven by } \\
\text { decision makers' political- } \\
\text { embeddedness, but not } \\
\text { their firm-embeddedness. }\end{array}$ \\
\hline $\begin{array}{l}\text { Chen, Li } \\
\text { and Fan }\end{array}$ & $\begin{array}{l}\text { CPC affect } \\
\text { MNE location } \\
\text { choice (high- } \\
\text { vs. low- } \\
\text { distance } \\
\text { countries) }\end{array}$ & $\begin{array}{l}2012- \\
2013\end{array}$ & $\begin{array}{l}75 \text { Chinese } \\
\text { high-tech } \\
\text { MNCs } \\
\text { investing in } \\
28 \text { host } \\
\text { countries }\end{array}$ & Survey & $\begin{array}{l}\text { Survey measures } \\
\text { based on Peng and } \\
\text { Luo (2000) }\end{array}$ & $\begin{array}{l}\text { Home and } \\
\text { host- } \\
\text { China and } \\
\text { worldwide }\end{array}$ & $\begin{array}{l}\text { Investments in high- and } \\
\text { low-distance countries are } \\
\text { associated with different } \\
\text { configurations of CPC, } \\
\text { largely depending on the } \\
\text { gestalts of firms' resource } \\
\text { base and industry } \\
\text { dynamics. }\end{array}$ \\
\hline
\end{tabular}




\begin{tabular}{|c|c|c|c|c|c|c|c|}
\hline $\begin{array}{l}\text { Liu, Yang } \\
\text { and } \\
\text { Augustine }\end{array}$ & $\begin{array}{l}\text { Contingencies } \\
\text { of CPC affect } \\
\text { firm } \\
\text { performance }\end{array}$ & $\begin{array}{l}\text { Study } \\
1: \\
2012- \\
2014 \\
\\
\text { Study } \\
2: \\
1999- \\
2014\end{array}$ & $\begin{array}{l}\text { Study 1: } 363 \\
\text { small- and } \\
\text { medium- } \\
\text { sized firms } \\
\text { Study 2: } \\
2,780 \\
\text { publicly } \\
\text { listed firms }\end{array}$ & $\begin{array}{l}\text { Study 1: Survey } \\
\text { Study 2: Wind dataset } \\
\text { and annual reports }\end{array}$ & $\begin{array}{l}\text { Study 1: Survey } \\
\text { measure based on } \\
\text { Peng \& Luo (2000) } \\
\text { Study 2: Board of } \\
\text { directors' prior } \\
\text { political } \\
\text { experiences }\end{array}$ & $\begin{array}{l}\text { Domestic- } \\
\text { China }\end{array}$ & $\begin{array}{l}\text { Both studies find that the } \\
\text { relationships between CPC } \\
\text { and firm performance are } \\
\text { positively mediated by the } \\
\text { proself and prosocial } \\
\text { engagement of the firm. } \\
\text { Further, institutional } \\
\text { development weakens the } \\
\text { mediation effect on the } \\
\text { link between CPC and } \\
\text { firm performance through } \\
\text { proself engagement but } \\
\text { strengthens the mediation } \\
\text { effect on this link through } \\
\text { prosocial engagement. }\end{array}$ \\
\hline $\begin{array}{l}\text { Brown, } \\
\text { Yasar and } \\
\text { Rasheed }\end{array}$ & $\begin{array}{l}\text { Antecedents } \\
\text { of CPC: } \\
\text { impact of } \\
\text { home country } \\
\text { institutions }\end{array}$ & $\begin{array}{l}1998- \\
2014\end{array}$ & $\begin{array}{l}1,701 \\
\text { publicly } \\
\text { listed } \\
\text { foreign } \\
\text { firms across } \\
37 \text { different } \\
\text { countries }\end{array}$ & $\begin{array}{l}\text { Multiple data sources, } \\
\text { such as Federal } \\
\text { Election Commission, } \\
\text { Uniworld, and } \\
\text { Compustat }\end{array}$ & $\begin{array}{l}\text { Dollar amount } \\
\text { spent on lobbying }\end{array}$ & $\begin{array}{l}\text { Home } \\
\text { impact on } \\
\text { host } \\
\text { activity- } \\
\text { worldwide } \\
\text { and USA }\end{array}$ & $\begin{array}{l}\text { MNEs from countries with } \\
\text { high individualism and } \\
\text { low in uncertainty } \\
\text { avoidance are more likely } \\
\text { to engage in corporate } \\
\text { political activity (CPA) in } \\
\text { the USA. MNEs from } \\
\text { countries that are less } \\
\text { corrupt or higher in } \\
\text { administrative distance } \\
\text { from the USA are more } \\
\text { likely to engage in CPA. }\end{array}$ \\
\hline
\end{tabular}


[Authors' final version] 